\title{
Management of hepatitis C patients with kidney failure
}

\section{Renal yetmezlikli hepatit C hastalarının yönetimi}

\author{
Emine Parlak ${ }^{* *}$ \\ ${ }^{1}$ Atatürk University Medical Faculty Department of Infectious Diseases and Clinical Microbiology, Erzurum, Turkey \\ * Corresponding author: Emine Parlak E-mail: eparlak1@yahoo.com ORCID: 0000-0001-8912-6360 \\ Received: 6 November 2018 Accepted: 18 May 2019
}

\begin{abstract}
Chronic hepatitis $\mathrm{C}(\mathrm{CHC})$ infection is a significant health problem that affects 185 million people worldwide. Complications such as fibrosis, cirrhosis, liver failure and liver cancer may also develop. The hepatitis $\mathrm{C}$ virus (HCV) may also progress with non-hepatic involvement. At least one extrahepatic manifestation (EHM) is observed in two out of three of these patients. EHMs may not always be seen together with liver disease findings, and may even appear before clinical chronic viral hepatitis findings. HCV can be diagnosed earlier by means of careful systematic examination. EHMs such as kidney diseases, autoimmune diseases, hematological diseases, diabetes and cardiomyopathy may be encountered in chronic HCV. EHMs can cause morbidity and mortality. Contemporary effective, oral, direct-acting antiviral (DAA) drugs are the first-choice medications. Sustained virological response (SVR) and a high success rate can be achieved in HCV patients with access to these drugs. This report discusses the current status of HCV infection, EHMs, and the available therapeutic options in the treatment of renal failure.
\end{abstract}

Keywords: chronic hepatitis C, extrahepatic manifestation, direct-acting antiviral

() 2019 by the authors; licensee MEDITAGEM Ltd., Turkey. This article is an open access article distributed under the terms and conditions of the Creative Commons Attribution License (http://creativecommons.org/licenses/by/4.0/). 


\section{ÖZ}

Kronik Hepatit C (KHC) infeksiyonu önemli bir sağlık problemidir. Dünyada 185 milyon insanı etkilemiştir. Hastalarda fibroz, siroz, karaciğer yetmezliği, karaciğer kanseri gibi komplikasyonlar gelişebilir. Özellikle hepatit C virüsü (HCV) karaciğer dışı tutulumlarla da seyredebilir. Bu hastaların üçte ikisinde en az bir extrahepatik bulgu (EHB) izlenmektedir. EHB her zaman karaciğer hastalığı bulguları ile birlikte görülmez. Hatta kronik viral hepatit klinik bulgularından önce EHB çıkabilmektedir. Dikkatli yapılan sistematik muayene ile HCV tanısı daha erken konulabilir. Kronik HCV'de böbrek hastalıkları, otoimmun hastalıklar, hematolojik hastalıklar, diabet, kardiomyopati gibi EHB ile karşılaşabiliriz. EHB morbidite ve mortalite nedeni olabilir. Güncel etkili, oral, güvenilir direkt etkili antiviral (DEA) ilaçlar birincil tercih edilen ilaçlardır. Bu ilaçlara ulaşabilen HCV hastalarında sürekli virolojik yanıta (SVR) ulaşılabilmektedir. Yüksek başarı oranı sağlanmaktadır. Bu raporda HCV infeksiyonun güncel durumu, ekstrahepatik bulgular, renal yetmezlikte güncel yeni tedavi tercihlerine değinilecektir.

Anahtar kelimeler: kronik hepatit C, ekstrahepatik bulgular, direkt etkili antiviral

\section{INTRODUCTION}

$\mathrm{HCV}$ is an RNA lipid membrane-bearing virus from the genus Hepacavirus, from the family Flaviviridae, with six major genotypes and more than 100 subtypes. Ninety percent of chronic hepatitis $\mathrm{C}(\mathrm{CHC})$ patients in Turkey are infected with genotype 1 . The most commonly encountered genotype in Turkey is $1 \mathrm{~b}$. Hepatitis $C$ is transmitted by the parenteral route (by health workers, blood and blood product transfusion recipients, hemodialysis patients and iv drug dependents), sexually, perinatally, and by the intra-familial route [1]. The prevalence of hepatitis $C$ is less than $2 \%$ in developed countries. However, in Latin America, Western Europe, the former USSR, Western Africa, the Middle East and Southern Asia the prevalence is above $2 \%$. The highest prevalence is in Egypt, at approximately 10\% [2]. The prevalence in Turkey varies from region to region, but a general figure of approximately $1 \%$ has been determined at anti-HCV screening. Turkish provinces with prevalences of $1 \%$ or more include Afyon, Düzce, Erzurum, Manisa, and Samsun [3].

The prevalence of hepatitis $C$ increases with age. Reported anti-HCV positivity levels are $4.2 \%$ in the 50-59 age group, $3.4 \%$ in the 60-69 age group, and are highest, at 7.1\%, in the 70-79 age group [4]. Recent analysis has revealed chronic kidney disease (CKD) in $8.52 \%$ of HCV patients aged 20-64 and in $26 \%$ of those aged 65 or over [5]. Anti-HCV positivity is particularly high in CKD, hemodialysis, peritoneal dialysis and kidney transplantation patients. HCV infection is the most commonly determined cause of CKD in hemodialysis patients $[6,7]$.

The prevalence of anti-HCV positivity in hemodialysis patients cited by the Turkish Association for the Fight against Viral Hepatitis is $41.5 \%$ [8] while the Turkish Society of Nephrology reports a figure of $21.3 \%$ [9]. Köksal [10] reported an anti-HCV positivity rate of $31.4-51 \%$ in dialysis patients. However, anti-HCV (+) rates in kidney disease patients in Turkey have decreased significantly in recent years, with the Turkish Society of Nephrology reporting a figure of $6.64 \%$ at the end of 2014 [11]. In the last 20 years, positivity has decreased from approximately $50 \%$ to $6 \%$ in hemodialysis patients and from approximately $25 \%$ to $3 \%$ in peritoneal dialysis patients. Anti-HCV positivity of $3-10 \%$ has been observed in hemodialysis centers in Europe and the USA $[12,13]$. Kheirabad et al. reported anti-HCV positivity in 149 patients entering hemodialysis [14].

\section{The Causes of HCV Infection Epidemics in Hemodialysis Units}

Failure to disinfect equipment, combined use of drugs involving multiple doses such as heparin, failure to routinely clean and disinfect dialysis machines, failure to immediately remove spilled blood, cross-contamination of health personnel working in hemodialysis units, nosocomial transmission, the presence of anti-HCV positive patients in the hemodialysis unit, sex (male>female), history of renal transplantation, intravenous drug use, transfusions of blood and blood products, and frequent medical test requirements (endoscopic tests, surgical procedures, etc.) have all been reported among the causes of HCV infection [15].

Risk factors for HCV infection in hemodialysis patients include blood transfusion, the amount of blood transfused, and duration of dialysis. The prevalence of HCV infections increases in line with duration of dialysis. Length of dialysis is an independent risk factor for high HCV infection $[15,16,17]$.

The anti-HCV test can give unreliable results in the event of autoimmune disease or spontaneous resolution of viral 
Table 1. Extrahepatic Manifestations of HCV infection [24]

\begin{tabular}{|l|l|l|l|l|}
\hline $\begin{array}{l}\text { Definitely related, as proved by } \\
\text { pathogenetic studies and } \\
\text { comorbidity incidence }\end{array}$ & $\begin{array}{l}\text { Relation identified with relatively } \\
\text { higher comorbidity rates } \\
\text { compared to controls }\end{array}$ & Probably associated & $\begin{array}{l}\text { Anecdotal observational } \\
\text { association finding }\end{array}$ & \\
\hline Mixed cryoglobulinemia & B-cell NHL & Autoimmune thyroiditis & Psoriasis & Fibromyalgia \\
\hline & Monoclonal gammopathies & Thyroid cancer & Peuropheral/central & Chronic urticaria \\
\hline & Porphyria cutanea tarda & Sicca syndrome & Chronic polyarthritis & Chronic pruritus \\
\hline & Lichen planus & Alveolitis-lung fibrosis & Rheumatoid arthritis & Kaposi's pseudo-sarcoma \\
\hline & & Diabetes mellitus & Polyarthritis nodosa & Vitiligo \\
\hline & & $\begin{array}{l}\text { Non-cryoglobulinemic } \\
\text { nephropathies }\end{array}$ & Behcet's syndrome & Cardiomyopathies \\
\hline & & Aortic atherosclerosis & Poly/dermatomyositis & Mooren's corneal ulcer \\
\hline & & & Erectile dysfunctions & Necrolytic acral erythema \\
\hline
\end{tabular}

infection. It can also give unreliable results in patients with chronic immune suppression, transplant recipients, dialysis patients with chronic kidney failure, and HIV-positive patients $[18,19]$. Biochemical evidence of active liver disease may not be observed in hemodialysis patients, and anti-HCV may be negative $[15,17]$. The HCVcAg test is important in the identification and monitoring of viral replication. This can be determined 4-50 days before anti-HCV. It can be used before transplantation and transfusion and for screening high-risk groups (hemodialysis, IVDU and HIV). Apart from examples of a low viral load, it has also been reported to be useful in diagnosis and screening in hemodialysis patients. The test has high sensitivity and specificity in this patient group. It is also recommended as a quantitative marker in the monitoring of antiviral therapy and for the determination of viral replication in patients infected with HIV and not receiving treatment [19].

Extrahepatic manifestations (EHMs) associated with chronic $\mathrm{HCV}$ infection are frequently encountered in clinical practice. At least one EHM is observed during the course of the disease in $74 \%$ of patients diagnosed with chronic HCV, although the reason for this is unclear [20]. These findings have been attributed to increased oxidative stress and cytokine release in some studies. EHMs are also more common in the elderly, female patients, subjects with increased hepatic fibrosis and patients with a greater infection age [21].

The principal manifestations are essential mixed cryoglobulinemia, B cell non-Hodgkin's lymphoma, seronegative arthritis, keratoconjunctivitis sicca, sialadenitis, lichen planus, neuropathies, neurocognitive disorders and porphyria cutanea tarda, all conditions with a significant deleterious impact on quality of life [22].

Essential mixed cryoglobulinemia is also known as type 2 cryoglobulinemia and is the most common EHM encountered in HCV. It is a lymphoproliferative disease occurring with immune complex in small- and mediumdiameter vessel walls. Arthritis attacks, diffuse arthralgia, purpuric eruptions and glomerular kidney disease are frequently seen. The disease also has a well-known association with chronic HCV infection [23].

Several autoimmune diseases may develop in association with the course and treatment of HCV infection. Reported conditions include rheumatoid arthritis, Sjögren's syndrome, systemic lupus erythematosus, polyarteritis nodosa, and antiphospholipid syndrome (Table 1) [24].

Hepatitis $C$ infection frequently causes renal involvement associated with mixed cryoglobulinemia, membranoproliferative glomerulonephritis (GN), membranous GN and polyarteritis nodosa. Other less common associations include crescentic $\mathrm{GN}$, focal segmental glomerulosclerosis, proliferative GN, fibrillary GN, and immunotactoid GN [7]. HCV infection is also associated with renal function losses. Increased albuminuria, a decrease in the estimated glomerular filtration rate (eGFR), kidney failure progression, and even kidney disease-related mortality have been reported in infected patients $[25,26]$. HCV infection exacerbates kidney disease-related morbidity and mortality $[7,27,28]$. The Kidney Disease: Improving Global Outcomes (KDIGO) guideline recommends that patients with CKD be screened for hepatitis C [29].

Interferon was previously recommended in CKD patients. However, the response to interferon therapy was much lower in genotype 1 compared to genotypes 2 and 3 . Ribavirin is reported to be contraindicated due to the risk of life-threatening hemolysis [29,30].

Numerous novel diagnostic agents (DAAs) have been licensed since 2014. Interferon-free regimens subsequently entered into routine clinical use (27). CKD consists of five phases, as shown in Table 2 [31]. The selection of DAAs in patients with CKD is determined based on the HCV 
Table 2. Stages of Chronic Kidney Disease [31]

\begin{tabular}{|c|l|c|c|}
\hline Stage of CKD & Description & GFR mL/min/1.73 m2 & Prevalence \% \\
\hline 1 & Kidney damage with normal or increased GFR & $60-89$ & 2.8 \\
\hline 2 & Kidney damage with mild decrease in GFR & $30-59$ & 2.8 \\
\hline 3 & Moderate decrease in GFR & $15-29$ & 3.7 \\
\hline 4 & Severe decrease in GFR & $<15$ & 0.1 \\
\hline 5 & Kidney failure & 0.2 & \\
\hline
\end{tabular}

genotype, viral load, eGFR, other drugs used concomitantly, comorbidities, and transplant status [28].

Eight end-stage renal disease (ESRD) patients infected with HCV were started on full-dose sofosbuvir/simeprevir or sofosbuvir/ledipasvir in one recent study. Six of these patients were genotype 1 . No cardiac or hepatobiliary toxicity was observed in any cases, and no patients discontinued treatment due to side-effects. However, one patient died during follow-up. Sustained virological response at week 12 (SVR12) thus developed in seven patients [32].

Fifty HCV-positive patients (36 male/14 female) with severe renal failure were started on sofosbuvir-based treatments in another study. Thirty-five of these were hemodialysis patients, and 21 were genotype $1 \mathrm{~b}$. Patients were started on sofosbuvir/ribavirin $(n=7)$, sofosbuvir/RBV/pegylated interferon ( $n=2)$, sofosbuvir /daclatasvir \pm RBV $(n=30)$, or sofosbuvir /simeprevir \pm RBV $(n=11)$ as antiviral therapies. Hemodialysis patients used reduced-dose sofosbuvir (400 $\mathrm{mg}$ three times a week, or $400 \mathrm{mg}$ every other day). SVR12 was determined in $86 \%$ of patients [33].

A poster exhibited at the European Association for the Study of the Liver in 2015 reported that seven patients with genotype $1 \mathrm{a}$, and nine with chronic kidney failure (CKF) or ESRD were treated with full-dose sofosbuvir. Seven patients with ESRD were in the hemodialysis program. One patient was excluded due to stroke. SVR was determined at a rate of $89 \%$ on the $12^{\text {th }}$ week of the study. The authors finally concluded that a full-dose sofosbuvir regimen was safe for dialysis patients despite the contradictory data elicited [34]. Sofosbuvir has a high genetic barrier and is of very great importance for the treatment of HCV. However, it is contraindicated in severe kidney failure in some countries. Further, wide-ranging studies are still needed on this subject [35]. Nonetheless, sofosbuvir-based regimens can be used when emergency treatment is required due to liver disease and drug-drug interaction [40]. Sofosbuvir is the only DAA drug expelled from the kidney $[27,28]$. Since the others are essentially metabolized from the liver, there is no need for dose adjustment in CKD patients [36].
In one study from Spain involving 33 patients and reporting true life data, seven patients had stage 4 renal failure and 26 had stage 5 renal failure. Seventy percent of patients were genotype $1 \mathrm{~b}$, and $25 \%$ were treatment-experienced. Patients were started on ombitasvir/paritaprevir/ $r /$ and dasabuvir \pm ribavirin $200 \mathrm{mg} /$ day (OBV/PTV/ $\mathrm{r} \pm \mathrm{DSV} \pm \mathrm{RBV}$ ). One hundred percent SVR12 results were achieved [37].

A poster presented at the EASL in 2016 reported the enrolment of 1712 patients. Sixty percent of these were genotype $1 \mathrm{~b}$. Fifty-five of the 116 CKD patients were stage $3 b, 21$ were stage 4,40 were stage 5 , and 34 were hemodialysis patients. Patients were started on sofosbuvir/ribavirin $(n=4)$, sofosbuvir/ledipasvir $(n=20)$, ombitasvir/paritaprevir/r (2D)/ ombitasvir ritonavir with paritaprevir and dasabuvir) 3D $(n=12)$, sofosbuvir/daclatasvir $(n=14)$, simeprevir/daclatasvir $(n=48)$, or sofosbuvir+simeprevir $(n=18)$ as antiviral therapies. Effectiveness was shown to be independent of genotype, viral load, presence of cirrhosis, antiviral regimens, or ribavirin. SVR rates were also achieved independently of anemia development and ribavirin dose adjustment [38].

One study employed PubMed to screen studies published between 2014 and 2016, revealing that 350 CKD patients with $\mathrm{CHC}$ and using DAAs had been investigated. Apart from one randomized controlled study examining elbasvir and grazoprevir therapy, all the other study populations consisted of small groups. Similar result and side-effect profiles were observed in patients with and without CKD. DAA drug therapy was assessed as highly effective in CKD patients. The best evidence for patients with HCV genotype (GT) 1a, $1 \mathrm{~b}$ or 4 and stage 4 or 5 CKD patients was for elbasvir and grazoprevir use. For patients infected with HCV genotype 1, the combination of paritaprevir, ritonavir, ombitasvir and dasabuvir is also indicated. These drugs were reported to be well tolerated, and examination of SVR at 12 weeks revealed rates of $90-100 \%$ [39].

I examined studies involving the DAA grazoprevir/elbasvir (GZR/EBR) and published on Pubmed and Cochrane in 20052016. The novel oral combination GZR/EBR received U.S. Food and Drug Administration approval for advanced kidney disease patients and hemodialysis patients. Various 
Table 3. Patients with Renal Impairment AASLD [46]

\begin{tabular}{|c|c|}
\hline Recommendations for Patients with CKD Stage 1,2 , or 3 & $\begin{array}{l}\text { Patients with CKD Stage } 4 \text { or } 5 \text { (eGFR }<30 \mathrm{~mL} / \mathrm{min} \text { or End-Stage Renal } \\
\text { Disease) }\end{array}$ \\
\hline Daclatasvir (60 mg) & $\begin{array}{l}\text { Daily fixed-dose combination of elbasvir }(50 \mathrm{mg}) / \text { grazoprevir }(100 \mathrm{mg}) 1 \mathrm{a}, \\
1 \mathrm{~b}, 4 \text { (12 weeks) }\end{array}$ \\
\hline Daily fixed-dose combination of glecaprevir (300 mg)/pibrentasvir $(120 \mathrm{mg})$ & $\begin{array}{l}\text { Daily fixed-dose combination of glecaprevir ( } 300 \mathrm{mg}) / \text { pibrentasvir }(120 \mathrm{mg}) \\
1,2,3,4,5,6 \text { (8 to } 16 \text { weeks) }\end{array}$ \\
\hline \multicolumn{2}{|l|}{ Fixed-dose combination of sofosbuvir ( $400 \mathrm{mg}$ )/velpatasvir ( $100 \mathrm{mg}$ ) } \\
\hline \multicolumn{2}{|l|}{$\begin{array}{l}\text { Fixed-dose combination of sofosbuvir }(400 \mathrm{mg}) / \text { velpatasvir (100 } \\
\mathrm{mg}) / \text { voxilaprevir }(100 \mathrm{mg})\end{array}$} \\
\hline \multicolumn{2}{|l|}{ Daily fixed-dose combination of elbasvir (50 mg)/grazoprevir (100 mg) } \\
\hline \multicolumn{2}{|l|}{ Fixed-dose combination of ledipasvir (90 mg)/sofosbuvir (400 mg) } \\
\hline \multicolumn{2}{|l|}{ Simeprevir (150 mg) } \\
\hline Sofosbuvir (400 mg) & \\
\hline
\end{tabular}

Chronic kidney disease (CKD) stages: $1=$ normal (eGFR $>90 \mathrm{~mL} / \mathrm{min}$ ); $2=$ mild CKD (eGFR 60-89 mL/min); $3=$ moderate CKD (eGFR 30-59 ml $/ \mathrm{min}$ ); $4=$ severe CKD (eGFR 15-29 mL/min); 5 = end-stage CKD (eGFR $<15 \mathrm{~mL} / \mathrm{min})$

studies have shown that elbasvir and grazoprevir can be used in standard doses in all stages of CKD [40]. One phase 3 study published in the Lancet and using a grazoprevir/elbasvir combination reported a SVR12 rate of $94.3 \%(115 / 122)$. This was a particularly important study in terms of the patients being genotype 1 and including CKF stages 4 and 5 [41].

Twenty-one patients infected with HCV and receiving an asunaprevir (ASV) and daclatasvir (DCV) combination were evaluated in another study, and SVR 12 rates of $95.5 \%$ (20/21) were reported [42]. Toyoda et al. [43] used ASV/DCV combination therapy with 28 dialysis patients and 56 patients with no kidney disorder. SVR12 rates were $100 \%$ $(28 / 28)$ in the dialysis patients and $94.6 \%$ in the subjects with normal renal functions. The authors showed that HCV RNA was eliminated considerably earlier in hemodialysis patients.

Priority must be attached to subjects with a high risk of HCV transmission, such as long-term hemodialysis patients, whose risk of transmission will decrease when treated. Treatment is also recommended in patients with clinically significant EHMs (such as HCV-related cryoglobulinemia) $[44,45]$.

Glecaprevir and pibrentasvir have been determined to be effective in CHCV infection with CKD independent of stage in the six major genotypes [45]. This recommendation has been reflected in the guidelines as a daily full-dose glecaprevir and pibrentasvir combination. The American Association for the Study of Liver Diseases recommendation is shown in Table 3 [46].

The Turkish Diagnosis and Treatment of Viral Hepatitis Guideline 2017 also reported recommendations for chronic kidney disease patients among special patient groups. Treatment is indicated in subjects with GFR $<30 \mathrm{ml} / \mathrm{min} / 1.73$ $\mathrm{m} 2$ or entering hemodialysis and in whom kidney transplantation cannot be performed. It is recommended that patients infected with genotype $1 \mathrm{a}$ receive: paritaprevir+ritonavir+ombitasvir+dasabuvir+ribavirin (200 $\mathrm{mg} /$ day) for 12 weeks, and grazoprevir+elbasvir for 12 weeks. Ribavirin must not be used if $\mathrm{Hgb}<10 \mathrm{~g} / \mathrm{dl}$ or $<8.5$ $\mathrm{g} / \mathrm{dl}$ during treatment, and treatment should be extended to 24 weeks. Paritaprevir+ritonavir+ombitasvir+dasabuvir for 12 weeks grazoprevir+elbasvir for 12 weeks, and daclatasvir+asunaprevir for 24 weeks are recommended in patients infected with genotype $1 \mathrm{~b}$ [47].

According to the Turkish Health Implementation Directive, the general rule in the treatment of $\mathrm{CHC}$ is that genotype screening should be performed in HCV RNA-positive patients. Rules for liver biopsy were determined based on ISHAK (modified Knodell score) scoring. CHC treatment is started in patients with fibrosis grade 1 and above based on ISHAK scores. Patients who have not previously received chronic hepatitis $C$ treatment; 1 ) Treatment in genotype 1 patients; b) treatment in cirrhotic patients; 1- Genotype 1a and genotype $1 \mathrm{~b}$ (child $\mathrm{A}, \mathrm{B}$ or $\mathrm{C}$ ): Total duration of (Sofosbuvir + Ledipasvir) + Ribavirin therapy is 12 weeks. 2Genotype $1 \mathrm{a}$ and genotype $1 \mathrm{~b}$ (child A, B or C): The total duration of sofosbuvir + ledipasvir therapy is 24 weeks. 3Genotype 1b (Child A): Total duration of (Ombitasvir + Paritaprevir + Ritonavir) + Dasabuvir therapy is 12 weeks. 4Genotype 1a (Child A): Total duration of (Ombitasvir + Paritaprevir + Ritonavir) + Dasabuvir + (Ribavirin) therapy is 24 weeks [48].

In conclusion, $\mathrm{CHC}$ infection is a curable disease. High rates of HCV infection are seen in the CKD patient group, 
particularly in hemodialysis patients. It also causes significant morbidity and mortality. EHMs are common in CHC patients, and may sometimes appear before hepatic involvement. Improvement in EHM is achieved with the virus being eliminated with hepatitis $C$ treatment. The treatment decision varies, depending on CKD stage, the speed of progression of the disease, and the patient's suitability for kidney transplantation. New treatments possess the advantages of high efficacy and shortening treatment. Sofosbuvir, simeprevir and daclatasvir are recommended for subjects with a glomerular filtration rate $>30 \mathrm{ml} / \mathrm{min}$. Elbasvir / grazoprevir and glecaprevir / pibrentasvir are recommended for use in advanced stage (stages 4, and 5) kidney patients.

\section{DECLARATION OF CONFLICT OF INTEREST}

The authors received no financial support for the research and/or authorship of this article. There is no conflict of interest.

\section{REFERENCES}

1. Tabak F. Kronik hepatit C'de güncel tedavi. ANKEM Derg. 2013;27(Ek 2):135-136.

2. Mohd Hanafiah K, Groeger J, Flaxman AD, Wiersma ST. Global epidemiology of hepatitis $C$ virus infection: new estimates of age-specific antibody to HCV seroprevalence. Hepatology. 2013;57:1333-1342.

3. Türk Karaciğer Araştırmaları Derneği Ulusal Hepatit Sıklığı Çalışması (TÜRKHEP 2010) www.tasl.org.tr/dosya/tasl Ulusal Hepatit Sıklığı Çalışması.

4. Yildirim B, Barut S, Bulut $Y$, et al. Seroprevalence of hepatitis $B$ and $C$ viruses in the province of Tokat in the Black Sea region of Turkey: A population-based study. Turk J Gastroenterol. 2009;20(1):27-30.

5. Senaka Peter, Craig Solid, Tanya Bovitz, Haifeng Guo, Allan J. Collins, Jean Marie Arduino. Hepatitis $C$ and renal disease: differences in patient characteristics and clinical outcomes in the United States. Hepatology 2015; 62(suppl):1120A; (poster 1867)

6. Kidney Disease: Improving. Global Outcomes. KDIGO clinical practice guidelines for the prevention, diagnosis, evaluation, and treatment of Hepatitis $C$ in chronic kidney disease. Kidney International. 2008;73 (Suppl 109):1-99.
7. Oruç A, Ersoy A. Kronik böbrek hastalığında hepatit $C$ virüs enfeksiyonunun tedavisinde güncel yaklaşımlar. Turk Neph Dial Transpl. 2016;25(Ek / Suppl 1):31-40.

8. Mıstık R, Balık ì. Türkiye'de viral hepatitlerin epidemiyolojik analizi. Ed. Tekeli E, Balık I. Viral Hepatit. 1. Baskı. Karakter Color A.Ş. Viral Hepatitle Savaşım Derneği Yayını, 2003:9-55.

9. Türk Nefroloji Derneği merkezlerden gelen bilgilerin analizi dönem 2003, http://www.tsn.org.tr/registry/ Registry_2003.pdf

10. Koksal I. Pegylated interferon for treatment in hemodialysis patients with chronic hepatitis C. J Gastroenterol Hepatol. 2006 Mar;21(3):491-494.

11. Türk Nefroloji Derneği merkezlerden gelen bilgilerin analizi, dönem 2014. T.C. Sağlık Bakanlığı Ve Türk Nefroloji Derneği Ortak Raporu, Ankara. 2015: Türk Nefroloji Derneği Yayınları.

12. Finelli L, Miller JT, Tokars Jl, Alter MJ, Arduino MJ. National surveillance of dialysis-associated diseases in the United States, 2002. Semin Dial. 2005;18:52-61.

13. Alter J, Tokars Jl, Arduina MJ, Favero MS. Nosocomial infections with hemodialysis. In: Mayhall CG (ed). Hospital Epidemiology and Infection Control. 3 rd ed. Philadelphia: Lippincott Williams \& Wilkins, 2004:11391160.

14. Kheirabad K, Bahri F, Kargar M, Ghasemzadeh I. Hepatitis $C$ and $G$ Virus Infection Prevalence Among Hemodialysis Patients and Associated Risk Factors in the Hormozgan Province of Southern Iran. Hepat Mon. 2016;13;16(10):e40375.

15. CDC Recommendations for Preventing Transmission of Infections among Chronic Hemodialysis Patients. MMWR 2001;50(RR05):1-43.

16. Huang CC. Hepatitis in patients with end-stage renal disease. J Gastroenterol Hepatology. 1997;12(9-10):236241.

17. Lerouxs-Roels G, Dhondt A. Hepatitis and dialysis. Infectious problems in dialysis patients. In: Lameire $\mathrm{N}$, Mehta RL (eds). Complications of Dialysis. New York: Marcel Dekker, 2000:673-696.

18. Strader DB, Wright T, Thomas DL, Seeff LB. American Association for the Study of Liver Diseases. Diagnosis, Management, and Treatment of Hepatitis C. Hepatology. 2004;39(4):1147-1171. 
19. Ergünay K, Sener B, Alp A, Karakaya J, Hascelik G. Utility of commercial quantitative hepatitis $C$ virus core antigen assay in a diagnostic laboratory setting. Diagn Microbiol. Infect. Dis. 2011;70:486-491.

20. Cacoub P, Renou C, Rosenthal E, Cohen P, Loury I, Loustaud-Ratti V, Yamamoto AM, Camproux AC, Hausfater P, Musset L, Veyssier P, Raguin G, Piette JC. Extrahepatic manifestations associated with hepatitis $C$ virus infection. A prospective multicenter study of 321 patients. The GERMIVIC. Groupe d'Etude et de Recherche en Medecine Interne et Maladies Infectieuses sur le Virus de l'Hepatite C. Medicine (Baltimore). 2000;79(1):47-56.

21. Adinolfi LE, Nevola R, Lus G, Restivo L, Guerrera $B$, Romano C, Zampino R, Rinaldi L, Sellitto A, Giordano M, Marrone $A$. Chronic hepatitis $C$ virus infection and neurological and psychiatric disorders: an overview. World J Gastroenterol. 2015; 28;21(8):2269-2280.

22. Hofnagle JH. Course and outcome of hepatitis C. Hepatology. 2002;36(S1):21-29.

23. Agnello V, Chung RT, Kaplan LM. Arole for hepatitis $C$ virus infection in type II cryogloblunemi. N. Engl. J. Med 1992;19;327(21):1490-1495.

24. Zignego AL, Ferri C, Pileri SA, Caini P, Bianchi FB. Extrahepatic manifestations of Hepatitis $C$ Virus infection: a general overview and guidelines for a clinical approach. Italian Association of the Study of Liver Commission on Extrahepatic Manifestations of HCV infection. Dig Liver Dis. 2007;39(1):2-17.

25. Fabrizi F, Piergiorgio $M$, Martin P. The Unravelled Link between Chronic Kidney Disease and Hepatitis C Infection. New Journal of Science 2014. Article ID 180203. (doi: 10.1155/2014/180203).

26. Lucas GM, et al. Hepatitis C Viremia and the Risk of Chronic Kidney Disease in HIV-Infected Individuals. J Inf Dis 2013;208:1240-1249.

27. Cholongitas E, Pipili C, Papatheodoridis GV. Interferonfree regimens in patients with hepatitis $C$ infection and renal dysfunction or kidney transplantation. World $\mathrm{J}$ Hepatol. 2017;8;9(4):180-190.

28. Jadoul M, Martin P. Hepatitis C Treatment in Chronic Kidney Disease Patients: The Kidney Disease Improving Global Outcomes Perspective. Blood Purif. 2017;43(13):206-209.
29. KDIGO clinical practice guidelines for the prevention, diagnosis, evaluation, and treatment of hepatitis $C$ in chronic kidney disease. Kidney Disease: Improving Global Outcomes (KDIGO). Kidney Int Suppl. 2008;(109):1-99.

30. Carrion AF, Fabrizi F, Martin P. Should ribavirin be used to treat hepatitis $C$ in dialysis patients? Semin Dial. 2011;24(3):272-274.

31. Stevens LA, Coresh J, Greene T, Levey AS. Assessing kidney function-measured and estimated glomerular filtration rate. N Engl J Med. 2006;8;354(23):2473-83.

32. Singh T, Guirguis J, Anthony S, Rivas J, Hanouneh IA, Alkhouri N. Sofosbuvir-based treatment is safe and effective in patients with chronic hepatitis $\mathrm{C}$ infection and end stage renal disease: a case series. Liver Int. 2016;36(6):802-806.

33. Dumortier J, Bailly F, Pageaux GP, Vallet-Pichard A, Radenne $S$, Habersetzer F, Gagnieu MC, Grangé JD, Minello A, Guillaud O, Kamar N, Alric L, Leroy V. Sofosbuvir-based antiviral therapy in hepatitis $C$ virus patients with severe renal failure. Nephrol Dial Transplant. 2017;1;32(12):2065-2071.

34. Saxena, EASL, 2015, LP08. Journal of Hepatology 2015;63:763-773.

35. Suda G, Ogawa K, Kimura M, Nakai M,Sho T, Morikawa K, Sakamoto N. Novel Treatment of Hepatitis C Virus Infection for Patients with Renal Impairment. J Clin TransI Hepatol 2016;4:320-327.

36. Kiser JJ, Burton JR Jr, Everson GT. Drug-drug interactions during antiviral therapy for chronic hepatitis C. Nat Rev Gastroenterol Hepatol. 2013;10(10):596-606.

37. Gómeza RM, Rincónb D, Hernándezc E, Ahumadab A, Valderasb $P$, Izquierdod S, Devesad MJ, Fernándeze $C$, Gutiérreze ML, Ortizf M, Calvog M, Castellanoae G, Fernández I. Estudıo multıcéntrıco sobre la efıcacıa ysegurıdad en práctıca clínıca del tratamıento con ombitasvir/parıtaprevır/ritonavır más dasabuvır en pacientes con insuficiencia renal grave o nefropatía termınal e infección por el vhc gt1 y 4. 41st. Congreso Anual AEEH. 17-19 Feb, 2016. Madrid, Spain. P\#105. P105.

38. Efficacy and safety of HCV-treatment with Direct-Actıng Antıviral Agents Interferon-Free, in patients with severe renal impairment in clinical practice. EASL 2016, p. 179. 
39. Kohli A, Alshati A, Georgie F, Manch R, Gish RG. Directacting antivirals for the treatment of chronic hepatitis $C$ in patients with chronic kidney disease. Therap Adv Gastroenterol. 2016;9(6):887-897.

40. Papudesu C, Kottilil S, Bagchi S. Elbasvir/grazoprevir for treatment of chronic hepatitis $C$ virus infection. Hepatol Int. 2017;11(2):152-160.

41. Roth D, Nelson DR, Bruchfeld A, Liapakis A, Silva $M$, Monsour $\mathrm{H}$ Jr, et al. Grazoprevir plus elbasvir in treatment-naive and treatment-experienced patients with hepatitis $C$ virus genotype 1 infection and stage 4-5 chronic kidney disease (the C-SURFER study): a combination phase 3 study. Lancet. 2015;386:15371545 .

42. Suda G, Kudo M, Nagasaka A, Furuya K, Yamamoto $Y$, Kobayashi T, et al. Efficacy and safety of daclatasvir and asunaprevir combination therapy in chronic hemodialysis patients with chronic hepatitis C. J Gastroenterol. 2016;51:733-740.

43. Toyoda H, Kumada T, Tada T, Takaguchi K, Ishikawa T, Tsuji K, et al. Safety and efficacy of dual direct-acting antiviral therapy (daclatasvir and asunaprevir) for chronic hepatitis $C$ virus genotype 1 infection in patients on hemodialysis. J Gastroenterol 2016;51:741-747.
44. EASL Recommendations on Treatment of Hepatitis C 2016. J Hepatol (2016), https://doi.org/10.1016/j.jhep.2016.09.001 (Şubat 2018).

45. Kosloski MP, Zhao W, Marbury TC, Preston RA, Collins MG, Pugatch D, Mensa F, Kort J, Liu W. Effects of Renal Impairment and Hemodialysis on the Pharmacokinetics and Safety of the Glecaprevir and Pibrentasvir Combination in HCV-Negative Subjects. Antimicrob Agents Chemother. 2017 Dec 20. pii: AAC.01990-17. (doi: 10.1128/AAC.01990-17).

46. The American Association for the Study of Liver Diseases and the Infectious Diseases Society of America Present. HCV Guidance: Recommendations for Testing, Managing, and Treating Hepatitis $C$ Recommendations for Testing, Managing and Treating Hepatitis C, 2018. at: http://www.hcvguidelines.org Last Updated: September $21,2017$.

47. Türkiye Viral Hepatitler Tanı ve Tedavi Kılavuzu 2017.

48. Sağlık uygulama tebliği (SUT) 25 Mart 2017 CUMARTESi Resmî Gazete Sayı: 30018. 